\title{
Review of 130 years of research on cyanobacteria in aquatic ecosystems in Serbia presented in a Serbian Cyanobacterial Database
}

\author{
Zorica Svirčev, ${ }^{1,2}$ Nada Tokodi, ${ }^{1 *}$ Damjana Drobac ${ }^{1}$ \\ ${ }^{1}$ Department of Biology and Ecology, Faculty of Sciences, University of Novi Sad, Trg Dositeja Obradovića 3, 21000 Novi Sad, Serbia; \\ ${ }^{2}$ Department of Biochemistry and Pharmacy, Faculty of Science and Engineering, Åbo Akademi University, Tykistökatu 6 A, 20520 \\ Turku, Finland \\ *Corresponding author: nada.tokodi@dbe.uns.ac.rs
}

\begin{abstract}
The presence of toxic cyanobacteria in aquatic ecosystems in the territory of the Republic of Serbia was surveyed over a period of several decades. Increasing attention is being paid to some negative consequences that may be caused by these microorganisms. Information from available literary sources regarding the distribution and frequency of cyanobacteria and their toxins over a period of 130 years, together with the effects on humans and wildlife in aquatic ecosystems, were gathered and incorporated into a Serbian Cyanobacterial Database created for the CYANOCOST Action. This database encompasses information on 65 aquatic ecosystems, including rivers, lakes, ponds, canals, irrigation reservoirs, reservoirs used for drinking water supply and reservoirs used for other purposes. Cyanobacterial blooms were found in almost $80 \%$ of the investigated aquatic ecosystems. The analysis of the research showed the presence of more than 70 species, including blooms of 24 species from 13 genera. Five species of cyanobacteria: Microcystis aeruginosa, Aphanizomenon flos-aquae, Planktothrix agardhii, Microcystis flos-aquae and Planktothrix rubescens frequently formed blooms in the investigated waterbodies and cyanotoxins were also detected in some of them, which had certain negative effects. Here, we present an overview of data contained in the Serbian Cyanobacterial Database, concerning cyanobacterial distribution, cyanotoxin production and associated biological effects in different types of water bodies from the Republic of Serbia. Also, recent important and major cases of cyanobacterial blooming in reservoirs used for drinking water supply at Vrutci and Ćelije, the Aleksandrovac irrigation reservoir, the Ponjavica River and Lake Palić, including systematic research on the Lake Ludoš and few fishponds are further described. It can be concluded that cyanobacteria and cyanotoxins are omnipresent in different water bodies throughout the Republic of Serbia. For these reasons it is imperative to continue with the monitoring of cyanobacteria and cyanotoxins, as well as to continuously supplement the established database with new information. The Serbian Cyanobacterial Database represents a treasury of information on cyanobacteria and their toxins, and serves as a model for other countries in the region and beyond.
\end{abstract}

Key words: Cyanobacterial blooms; cyanotoxins; database; historical overview.

Received: 25 October 2016. Accepted: 23 January 2017.

\section{INTRODUCTION}

Research of algae in Serbia began over 130 years ago, with the publication of 'Fragmenta Phycologiae Bosniaco-Serbicae' by Scharschmidt (1883), who listed 46 algal species. The species were determined in samples of washed silt from herbarium specimens of the waterwheel plant (Aldrovanda vesiculosa (L.)) collected by the famous lecturer and botanist, Doctor Josif Pančić (Blaženčić, 1986). Over 50 species, mostly belonging to the green algae and cyanobacteria, were identified by Magnus, Simić and Katić during the late 19th and early 20th Centuries (Milovanović, 1949). Another notable name in this initial period of algal research was Nedeljko Košanin (Blaženčić, 1986).

World War I prevented further investigations of algae and cyanobacteria in Serbia, however, during the 1930s and 1940s exploration continued in the form of complex hydrobiological studies. A bibliographic review of the few Serbian algological studies until 1947 was presented by Milovanović (1949). This period is also important because it can be seen as the cradle of almost all of the subsequent trends in algal research (Blaženčić, 1986). After World War II, favorable conditions for more advanced, and continuous studies in this scientific area were created. During this period, the spatial distribution, seasonal dynamics and ecology of algae and cyanobacteria were investigated in springs, streams, rivers, ponds, swamps, canals, lakes and mineral waters, i.e., in most aquatic ecosystems in Serbia, which resulted in a wealth of data (Blaženčić, 1986).

Since the 1970s the field of research has been expanding as methods and techniques have been modernized. An increasing number of hydrobiologists, microbiologists and botanists are providing their contributions to the study of cyanobacteria in Serbia (Blaženčić, 1985). Undoubtedly the greatest contribution to the knowledge of algae and cyanobacteria has been given through the meticulous 
work of Prof. Jelena Blaženčić who performed systematic analysis and assessment of numerous aquatic ecosystems in Serbia.

Most recently, available data on the presence of cyanobacteria and their toxins in aquatic ecosystems in the Republic of Serbia were gathered and incorporated into the Serbian Cyanobacterial Database (SCDB) (https://cloud.pmf.uns.ac.rs/index.php/s/v6tErVCVcAuaXQN), as a result of the CYANOCOST Action. The objective of the present paper was to analyze, present and supplement available data from SCDB.

\section{DATA OVERVIEW}

Data on cyanobacterial occurrence, cyanotoxin production and the possible impact on humans and aquatic ecosystems in the Republic of Serbia were evaluated in over 70 data sources (Tab. 1). A comprehensive review of research articles, project reports, conference abstracts, dissertations, books, annual and news reports was performed, and collected data were entered into the SCDB. The analysis of the research showed that 65 different aquatic ecosystems had been investigated during the last 130 years. The microalgal and cyanobacterial research summarized in the SCDB consisted of over 250 analyses, of which most (about 150) were conducted since the year 2000. These analyses included determination of cyanobacteria, cyanotoxin detection and the documentation of associated biological effects and health incidents (Svirčev et al., 2014a).

Qualitative determination of cyanobacteria showed the presence of more than 70 species in the investigated aquatic ecosystems, with 24 species from 13 genera being recorded in blooms, the most frequent being Microcystis aeruginosa (Kützing), Aphanizomenon flos-aquae Ralfs ex Bornet \& Flahaul, Planktothrix agardhii (Gomont) K. Anagnostidis \& J. Komárek, Microcystis flos-aquae (Wittrock) Kirchner and Planktothrix rubescens (de Candolle ex Gomont) K. Anagnostidis \& J. Komárek (Svirčev et al., 2014a). All the Latin genera and species names are taken from the original publications. For the currently accepted nomenclature of the species cited in this paper, refer to the Supplementary Tab. 1. Cyanobacterial blooms were found in almost $80 \%$ of the investigated aquatic ecosystems. This paper summarizes their distribution, cyanotoxin production and associated biological effects in different types of waterbodies from the Republic of Serbia.

\section{Canals}

The canals in the Vojvodina region (Kralja Aleksandra canal and Kralja Petra canal) were explored during the 1930 s, when a bloom of M. aeruginosa was recorded (Protić, 1935). The cyanobacterium Anabaena flos-aquae (Dolichospermum flos-aquae (Brébisson ex Bornet \& Flahault) P. Wacklin, L. Hoffmann \& J. Komárek) also formed a mass occurrence in the Kralja Petra canal (Protić, 1936). Recently, most research was done on the Canal Danube-Tisa-Danube system where the presence of a common cyanotoxin, microcystin (MC), was detected. The highest concentrations (up to $347 \mu \mathrm{g} \mathrm{L}^{-1} \mathrm{MC}-\mathrm{LR}$ equivalents) were found in the autumn of 2006 at the locality of Bačko Gradište where the cyanobacterial species A. flos-aquae, Aph. flos-aquae, M. aeruginosa, M. flosaquae and Oscillatoria agardhii (Planktothrix agardhii) occurred (Simeunović, 2009).

\section{Ponds}

Very limited data are available on the occurrence of cyanobacteria and cyanotoxins in marsh-wetland ecosystems (Jakovljević and Stanković, 1931-1932; Milovanović, 1970; Pujin et al., 1987; Maslać et al., 1992; Subakov-Simić et al., 2004; Fužinato et al., 2010; Cvijan and Fužinato, 2011, 2012). Recent data from 2006 showed the first ocurrence of the invasive and potentially toxic cyanobacterial species Cylindrospermopsis raciborskii (Woloszynska) Seenayya \& Subba Raju in Slatina, a salt marsh pond (Cvijan and Fužinato, 2012). The presence of the cyanobacterial species M. aeruginosa in Rakina bara (Jakovljević and Stanković, 1931-1932), Aph. flos-aquae in Carska bara (Pujin et al., 1987) and Arthrospira

Tab. 1. Overview of the data in Serbian Cyanobacterial Database (1930-2012).

\begin{tabular}{|c|c|c|c|c|}
\hline Location & Cyanobacteria & Cyanotoxins & Biological effects & Reference \\
\hline $\begin{array}{l}\text { Canals (4) } \\
\text { Ponds (7) } \\
\text { Rivers (13) } \\
\text { Fishponds (8) } \\
\text { Reservoirs for irrigation (11) } \\
\text { Lakes (6) } \\
\text { Reservoirs for drinking water } \\
\text { supply (12) } \\
\text { Reservoirs with other purposes (4) }\end{array}$ & $\begin{array}{l}\text { Over } 70 \text { species found, } \\
\text { frequently blooming: } \\
\text { - Microcystis aeruginosa } \\
\text { - Aphanizomenon flos-aquae } \\
\text { - Planktothrix agardhii } \\
\text { - Microcystis flos-aquae } \\
\text { - Planktothrix rubescens }\end{array}$ & $\begin{array}{l}\text { Microcystin (MC) } \\
\text { Analyses: } \\
\text { - PPI } \\
\text { - ELISA } \\
\text { - HPLC } \\
\text { Detection in: } \\
\text { - Water } \\
\text { - Soil } \\
\text {-Plant tissues } \\
\text { - Fish tissues }\end{array}$ & $\begin{array}{l}\text { - Artemia salina bioassay } \\
\text { - Fish histopathology } \\
\text { - Animal mortality } \\
\text { - Epidemiological survey }\end{array}$ & $\begin{array}{l}\text { Over } 70 \text { literature sources: } \\
\text { - Peer-reviewed papers (24) } \\
\text { - International documents } \\
\text { (english) (10) } \\
\text { - National documents } \\
\text { (non-english) (40) } \\
\text { - Newspaper/internet reports (3) } \\
\text { - Own document (1) }\end{array}$ \\
\hline
\end{tabular}


fusiformis (Voronikhin) J. Komárek \& J.W.G. Lund in Slatina (Fužinato et al., 2010) causes some concerns as these species are known cyanotoxin-producers.

\section{Rivers}

Interestingly, there are a large number of data on cyanobacterial blooming in river ecosystems. One of the most publicized incidents happened in 2009 when the mortalities of fish and hundreds of cows and pigs which drank water from Ponjavica, the river near the town of Pančevo, occurred. The detected cyanobacterial species belonged to the genera Anabaena, Aphanizomenon, Aphanocapsa, Aphanothece, Chroococcus, Cylindrospermopsis, Geitlerinema, Jaaginema, Limnothrix, Microcystis, Phormidium, Planktothrix and Raphidiopsis. During 2008 and 2009 in the Ponjavica river, MCs (concentrations given as MC-LR equivalents in ELISA) were detected in the water (up to $4.84 \mathrm{mg} \mathrm{L}^{-1}$ ), sediment $(5.7 \mathrm{mg}$ per $100 \mathrm{~g}$ ), macrophytes (up to $5.0 \mathrm{mg}$ per $100 \mathrm{~g}$ ) and fish (up to $3.3 \mathrm{mg}$ per $100 \mathrm{~g}$ ), and the dominance of the invasive cyanobacterium Cyl. raciborskii was found (Karadžić, 2011; Natić, 2012; Karadžić et al., 2013). MCs may have contributed to the deaths of animals, however, the exact cause of death has not been determined.

MCs were also found in rivers Krivaja, Tamiš, Tisa and Begej, with the maximum concentrations of $80,33,32$ and $22 \mu \mathrm{g}$ MC-LR equivalents $\mathrm{L}^{-1}$ respectively, where $\mathrm{Aph}$. flos-aquae, M. flos-aquae and O. agardhii bloomed (Simeunović, 2009). These and other bloom-forming cyanobacteria, such as A. flos-aquae, M. aeruginosa and Oscillatoria rubescens (Planktothrix rubescens), were recorded in many rivers throughout the Republic of Serbia (Obušković, 1982, 1987, 1989, 1991; Sedmak and Svirčev, 2011).

\section{Fishponds}

Research on the occurrence of cyanobacteria in fishponds began with the investigations of the Ečka, Kolut and Živača fishponds where $M$. aeruginosa formed blooms (Milovanović and Živković, 1953, 1959; Milovanović, 1963), while Anabaena was found blooming in the Futog I fishpond (Ristić et al., 1979). In Kapetanski rit the presence of the invasive cyanobacterial species $C y l$. raciborskii was noted (Ćirić et al., 2010).

In the last five years, more attention has been turned to possible effects of cyanobacteria and their toxins on the quality of fish meat and cyanotoxin accumulation in fish tissues, that could consequently endanger the health of consumers. In fishponds with the code BO during 2010 and 2011, mass occurrences of cyanobacterial species Aph. flos-aquae, M. aeruginosa, Phormidium foveolarum (Leptolyngbya foveolara (Gomont) Anagnostidis \& Komárek ), Jaaginema subtilissimum (Kützing ex Forti) Anagnostidis \& Komárek, Pseudanabaena limnetica
(Lemmermann) Komárek and Geitlerinema amphibium (C. Agardh ex Gomont) Anagnostidis were recorded. Toxicity in an Artemia salina (L.) bioassay was detected in two of the six fishponds, when the maximum concentration of MCs in water amounted to $52 \mathrm{MC}-\mathrm{LR}$ equivalents $\mathrm{L}^{-1}$ in protein phosphatase inhibition (PPI) assay and 18 $\mu \mathrm{g} \mathrm{\textrm {L } ^ { - 1 }}$ in an enzyme-linked immunosorbent assay (ELISA). Besides water, MCs were found in the muscle and liver of fish, as well as in aquatic plants and sludge (World Bank Report, DM 4307 2011).

During the summer of 2011 in another fishpond, encoded MU (Fig. 1A), mass occurrences of G. amphibium, J. subtilissimum, M. aeruginosa, O. agardhii and Phor. foveolarum were recorded (World Bank Report, DM 4307 2011). The toxicity of water samples from the fishpond was confirmed by A. salina bioassay, and the presence of MCs and saxitoxin(s) in water was identified by a PPI assay and ELISA, respectively (Tokodi et al., 2013, 2014; Drobac, 2015; Drobac et al., 2016). The highest concentrations of MCs (181 $\mu \mathrm{g}$ MC-LR equivalents $\mathrm{L}^{-1}$ in the PPI assay) were detected in a water sample from September 2011 (Tokodi et al., 2014). The variant MC-RR was also detected in the muscle of fish Cyprinus carpio (L.) grown in the fishponds where high cyanobacterial occurrence was detected (Drobac, 2015; Drobac et al., 2016). Additionally, pathological alterations in the fish tissues of liver, kidneys, gills, intestine and muscle were also observed (Drobac, 2015; Drobac et al., 2016).

The observed adverse effects and accumulation of cyanotoxins in fish tissues show that cyanobacteria and their toxins in fishponds could be hazardous to fish quality, the economy, the consumers' health and the environment in general.

\section{Reservoirs used for irrigation}

Cyanobacteria and MCs were recorded in reservoirs in Serbia which are used for irrigation. Of 13 blooming species, the most frequently observed were Aph. flosaquae (Borkovac, Bukulja, Manđelos, Mrtva Tisa, Pavlovci, Provala, Zobnatica), O. agardhii (Borkovac, Mrtva Tisa, Pavlovci, Zobnatica), A. flos-aquae (Bukulja, Jegrička, Pavlovci) and M. flos-aquae (Koviljski rit, Pavlovci) (Đukić et al., 1991a, 1991b; Simeunović, 2009; Karadžić et al., 2010; Sedmak and Svirčev, 2011; Svirčev et al., 2013a). The highest concentration of $280 \mu \mathrm{g} \mathrm{L}^{-1}$ MC-LR equivalents in water was recorded in 2007 in Mrtva Tisa (Simeunović, 2009) when Aph. flos-aquae and O. agardhii were abundant (Fig. 1B).

Cyl. raciborskii was detected in September 2010 in the Aleksandrovac reservoir which is used for irrigation (Simić et al., 2011). An extensive fish mortality in Aleksandrovac occurred on 20 December 2012 and was associated with the presence of $C y l$. raciborskii blooming a few weeks before the incident. Almost the entire fish pop- 
ulation was killed (over 1.7 tonnes) including the species C. carpio, Silurus glanis (L.), Ctenopharyngodon idella (Valenciennes), Hypophthalmichthys molitrix (Valenciennes), Abramis brama (L.), Carassius gibelio (Bloch), Aspius aspius (L.), and Squalius cephalus (L.). A. salina bioassay showed high toxicity of water samples from Aleksandrovac. However, the most common cyanotoxins (MCs, cylindrospermopsin, and saxitoxin) were not detected. It is possible that some other unknown or undetected toxic metabolites of this cyanobacterium were present and were a potential cause of the fish mortality in Aleksandrovac (Drobac, 2015; Svirčev et al., 2016a).

Information about cyanotoxins in reservoirs used for irrigation is important because it is known that irrigation from water sources containing cyanobacteria and cyanotoxins may affect agricultural plants and lead to accumulation of these toxins. Therefore, the health risks to people and animals due to the consumption of agricultural products irrigated with cyanotoxin-containing water must be taken seriously (Codd et al., 1999; Crush et al., 2008; Saqrane et al., 2009; Chen et al., 2010; Drobac, 2015).

\section{Lakes}

In Gazivode Lake, Sjeničko Lake and Veliki Zaton Lake Anabaena circinalis (Dolichospermum circinale
(Rabenhorst ex Bornet \& Flahault) P. Wacklin, L. Hoffmann \& J. Komárek), A. flos-aquae and O. rubescens were observed in mass occurrences (Shllaku and Landner, 1992; Miljković et al., 2004; Sedmak and Svirčev, 2011). Detection of MCs was performed only in the lakes Palić and Ludoš.

Research from 2005 to 2007 shows the presence of MCs in Lake Palić, and the highest MC concentration, $389 \mu \mathrm{g}$ MC-LR equivalents $\mathrm{L}^{-1}$, was detected in the autumn of 2006. The most frequently blooming species was M. aeruginosa, followed by Anabaena spiroides (Dolichospermum spiroides (Klebhan) P. Wacklin, L. Hoffmann \& J. Komárek), A. circinalis, M. flos-aquae and Microcystis wesenbergii (Komárek) Komárek ex Komárek (Simeunović, 2009). In Lake Palić, fish mortality was observed by the author Seleši (1982), and this recurred in later years as well. In 2009 there was an extensive mortality of fish with loss of over 12 tonnes of fish stocks. Reasons cited included the lack of dissolved oxygen due to an excessive production of algae followed by their decay (http://www.zjzs.org.rs/page.php?id=286). Furthermore, in 2012 the invasive Cyl. raciborskii was also found in this lake (Institute of Public Health of Serbia, 2013).

In Lake Ludoš, MC concentrations reached up to 604
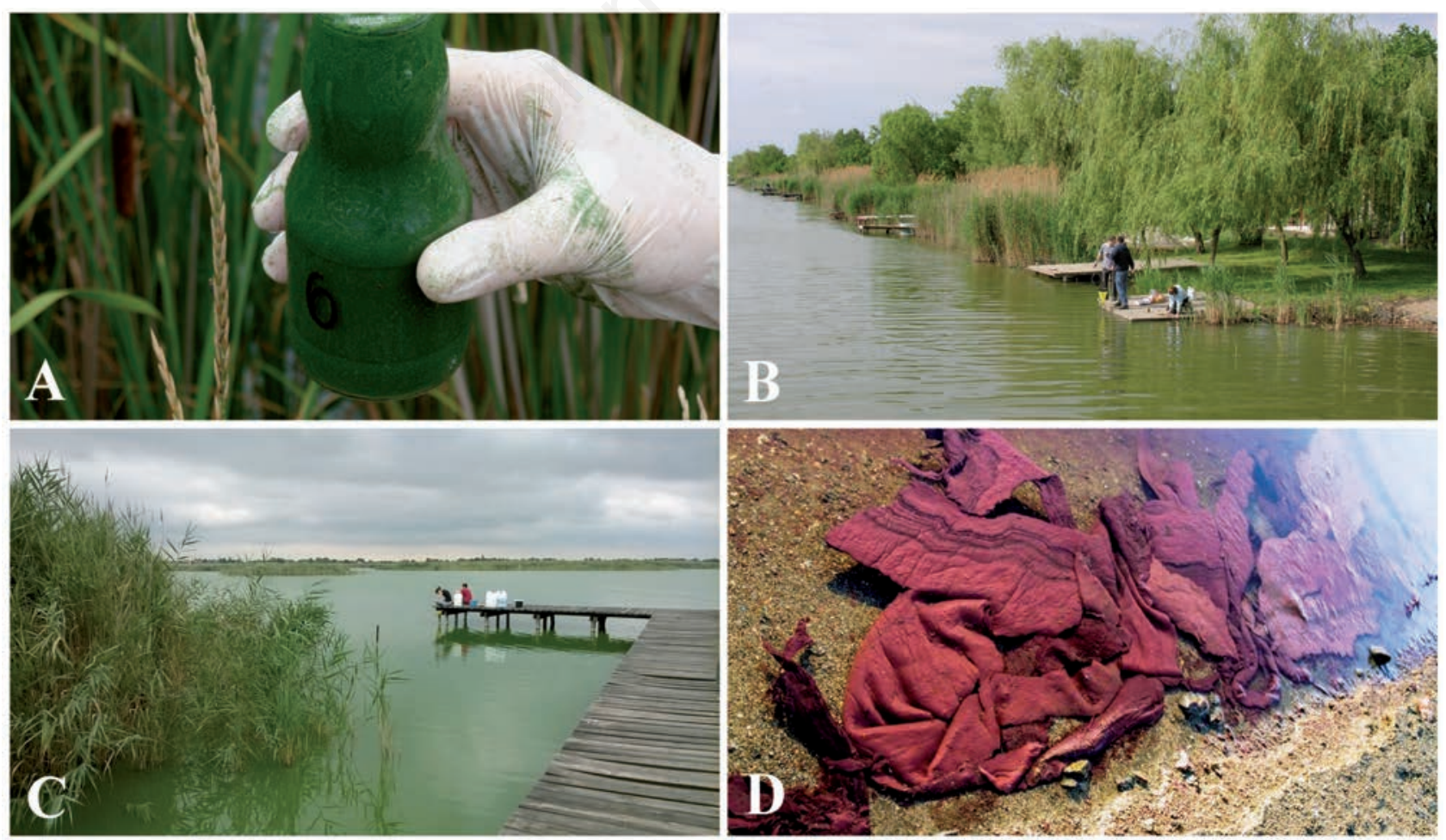

Fig. 1. Cyanobacterial blooming in fishpond (code MU) (A); reservoir used for irrigation (Mrtva Tisa) (B); lake (Lake Ludoš) (C); and reservoir used for drinking water supply (Vrutci) (D). 
$\mu \mathrm{g}$ MC-LR equivalents $\mathrm{L}^{-1}$ in the summer of 2006 , and the species that bloomed during the study period were Aph. flos-aquae, M. aeruginosa, M. flos-aquae, M. wesenbergii and P. agardhii (Simeunović, 2009). Research on Lake Ludoš during 2011 indicated not only MCs in the water, but also their accumulation in macrophytes (Phragmites communis Trin., Typha latifolia (L.) and Nymphaea elegans Hook.) and in the tissues (intestine, muscles, kidney, gills and gonads) of Prussian carp (C. gibelio). Histopathological changes in different organs of Prussian carp (liver, kidney, gills and intestines) from Lake Ludoš were associated with the high abundacies of potentially toxic cyanobacterial species Limnothrix redekei (van Goor) Meffert and P. limnetica that were found in the center of the lake (Fig. 1C). Given that Lake Ludoš is a Ramsar site, the stability of this aquatic ecosystem is of great and global importance (Tokodi, 2016).

\section{Reservoirs used for drinking water supply}

Unlike the Vojvodina region, where groundwater is used for water supply, central Serbia has a large number of surface reservoirs used for drinking water supply. There are more than 20 reservoirs used as sources of drinking water, and constant mass occurrences of cyanobacteria have been observed in nine of them (Svirčev et al., 2007).

In the following Serbian drinking water supply reservoirs: Bovan, Bresnica, Garaši, Grlište, Grošnica, Gruža, Krajkovac and Pridvorica, the emergence of the bloomforming cyanobacteria Anabaena solitaria (Dolichospermum solitarium (Klebahn) P. Wacklin, L. Hoffmann \& J. Komárek), Aph. flos-aquae, Gomphosphaeria lacustris (Snowella lacustris (Chodat) Komárek \& Hindák), Gomphosphaeria aponina Kützing, P. limnetica and M. aeruginosa has been documented, as has the presence of cyanotoxins in some of the reservoirs (Sedmak and Svirčev, 2011; Svirčev et al., 2014a). In Ćelije, the reservoir used for drinking water supply for the city of Kruševac, a bloom of A. circinalis, Aph. flos-aquae and $M$. aeruginosa was observed in 2004. MC was found in water samples from the reservoir $\left(650 \mu \mathrm{g} \mathrm{MC-LR} \mathrm{L}{ }^{-1}\right)$ and in the tap water $\left(2.5 \mu \mathrm{g} \mathrm{L}^{-1}\right)$ (Svirčev et al., 2009). In addition to the mentioned species, Aphanizomenon issatschenkoi (Cuspidothrix issatschenkoi (Usachev) P. Rajaniemi, Komárek, R. Willame, P. Hrouzek, K. Kastovská, L. Hoffmann \& K. Sivonen) (2001) and J. subtilissimum were detected in Ćelije (2007) (Svirčev et al., 2009; Sedmak and Svirčev, 2011). In Gruža, along with a bloom of Aph. flos-aquae, ultrastructural, apoptotic and necrotic changes in the liver of perch (Perca fluviatilis (L.)) were observed, as well as an impact on antioxidant biomarkers (Perendija et al., 2011).

Recently, cyanobacterial blooms of $P$. rubescens have occurred in Vrutci reservoir used for the water supply of the city of Užice (Fig. 1D), where 70.000 inhabitants were potentially exposed to cyanotoxins in December 2013. Based on the number of cells per $\mathrm{mL}$ and concentration of MCs, according to World Health Organization (WHO, 1999), water from reservoir Vrutci could be classified as a high-risk water for recreation and drinking water abstraction purposes. The results from $A$. salina bioassay showed significant toxicity of the cyanobacterial biomass. Modest fish mortality was observed during the cyanobacterial bloom, and MCs were detected in fish, including the muscle of frozen fish from 2013 which could indicate the presence of cyanobacteria even before the confirmed bloom. Furthermore, a questionnaire and epidemiological results showed that health problems possibly related to cyanotoxins (diseases of digestive system, skin and subcutaneous tissue) occurred already at least two years prior to the incident. This might be a sign that the population of the city of Užice could have been exposed to the cyanobacteria and cyanotoxins even two years before the observed bloom in 2013 (Svirčev et al., 2016b).

Chronic exposure to cyanotoxins (e.g. MCs) from drinking water could present a risk factor for primary liver cancer and possibly even other types of cancer (Svirčev et al., 2010; Drobac, 2015). Epidemiological studies conducted in Serbia have revealed a significant correlation between an increased incidence of several cancers (brain; heart, mediastinum and pleural; ovarian; testicular; gastric; colorectal; retroperitoneal and peritoneal; leukemia; malignant skin melanoma; and primary liver cancer) and cyanobacterial blooms in reservoirs used for drinking water supply (Svirčev et al., 2009, 2013b, 2014b; Drobac, et al. 2011; Drobac, 2015).

\section{Reservoirs used for other purposes}

Reservoirs used for hydropower generation have been poorly investigated. Three cyanobacterial species were noted: M. aeruginosa, Aph. flos-aquae and O. rubescens. Only $O$. rubescens formed mass occurrences in investigated reservoirs (Milovanović, 1973; Obušković, 1983; Sedmak and Svirčev, 2011).

\section{CONCLUSIONS}

Based on the reviewed data from our SCDB it can be concluded that cyanobacteria and cyanotoxins are omnipresent in different waterbodies throughout the Republic of Serbia. A systematic review and meta-analyses of the available literature is useful for an understanding of cyanobacterial biodiversity in Serbian waters. Some information is also available concerning the impact of cyanotoxins on other organisms, including humans. As a set of systemized data unique in the Balkan Peninsula, the database represents a possible model for other coun- 
tries in the region and beyond. Such databases encopassing all previous research (including monitoring and case reports), as well as continuous supplementation with the new available data are valuable in order to provide a timely and adequate reaction to toxic and noxious cyanobacteria, and thus prevent potential negative consequences.

\section{ACKNOWLEGDMENTS}

The authors would like to acknowledge the funding from the Ministry of Education, Science and Technological Development of the Serbian Government (project number: 176020) and COST Action ES1105 'CYANOCOST Cyanobacterial blooms and toxins in water resources: Occurrence, impacts and management' for adding value to this study through networking and knowledge-sharing with European experts in the field. The authors wish to thank Prof. Jelena Blaženčić for inspiration and scientific advice.

\section{REFERENCES}

Blaženčić J, 1986. [Review of development of algology in Serbia from 1883 to 1983].[Article in Serbian]. Glasnik instituta za botaniku i botaničke bašte Univerziteta u Beogradu 20:99-108.

Blaženčić J, Martinović-Vitanović V, Cvijan M, Filipi-Matutinović S, 1985. [Bibliografija radova o algama i algološkim istraživanjima u SR Srbiji od 1947. do 1980. godine].[Article in Serbian]. Glasnik instituta za botaniku i botaničke bašte Univerziteta u Beogradu 19:233-266.

Chen J, Dai J, Zhang H, Wang C, Zhou G, Han Z, Liu Z, 2010. Bioaccumulation of microcystin and its oxidative stress in the apple (Malus pumila). Ecotoxicology 19:796-803.

Ćirić M, Marković Z, Dulić Z, Subakov-Simić G, 2010. First report of cyanobacterium Cylindrospermopsis raciborskii from carp ponds in Serbia, p. 14. In: Proceedings 8th Int. Conf. on Toxic Cyanobacteria (ICTC8), Istanbul, Turkey.

Codd GA, Metcalf JS, Beattie KA, 1999. Retention of Microcystis aeruginosa and microcystin by salad lettuce (Lactuca sativa) after spray irrigation with water containing cyanobacteria. Toxicon 37:1181-1185.

Crush JE, Briggs LR, Sprosen JM, Nichols SN, 2008. Effect of irrigation with lake water containing microcystins on microcystin content and growth of ryegrass, clover, rape, and lettuce. Environ. Toxicol. 23:246-252.

Cvijan M, Fužinato S, 2011. The first finding of Cylindrospermopsis raciborskii (Woloszińska) Seenayya et Subba Raju 1972 (Cyanoprokaryota) in Serbia. Arch. Biol. Sci. 63:507-510.

Cvijan M, Fužinato S, 2012. Cylindrospermopsis raciborskii (Cyanoprokaryota)-potential invasive and toxic species in Serbia. Botanica Serbica 36:3-8.

Drobac D, 2015. [Putevi izloženosti čoveka cijanotoksinima i njihov uticaj na zdravlje].[PhD Thesis in Serbian], University of Novi Sad, Serbia.

Drobac D, Svirčev Z, Tokodi N, Vidović M, Baltić V, Božić-
Krstić V, Lazić D, Pavlica T, 2011. Microcystins - potential risk factors in carcinogenesis of primary liver cancer in Serbia. Geographica Pannonica 13:70-80.

Drobac D, Tokodi N, Lujić J, Marinović Z, Subakov-Simić G, Dulić T, Važić T, Nybom S, Meriluoto J, Codd GA, Svirčev Z, 2016. Cyanobacteria and cyanotoxins in fishponds and their effects on fish tissue. Harmful Algae 55:66-76.

Đukić N, Pujin V, Maletin S, Gajin S, Gantar M, Petrović O, Ratajac R, Seleši Đ, Matavulj M, 1991a. Lentic waters eutrophication in Vojvodina - Part I "Borkovac". Zbornik radova Instituta za biologiju 31:4-6.

Đukić N, Pujin V, Maletin S, Gajin S, Gantar M, Petrović O, Ratajac R, Seleši Đ, Matavulj M, 1991b. Lentic waters eutrophication in Vojvodina - Part I "Zobnatica". Zbornik radova Instituta za biologiju 31:39-40.

Fužinato S, Fodora A, Subakov-Simić G, 2010. Arthrospira fusiformis (Voronichina) Komarek et Lund (Cyanoprokaryota) - a new species for Europe. Algological Studies 134:17-24.

Institute of Public Health of Serbia, 2013. [Monitoring kvaliteta vode jezera Palić i Ludaš i potoka Kereš u 2012. godini].[Report in Serbian]. Institute of Public Health of Serbia, Belgrade.

Jakovljević S, Stanković S, 1931-1932. [Particularites limnologiques des eaux kartiques de la region de Belgrad].[Article in French]. Glasnik Botaničkog zavoda i bašte Univerziteta u Beogradu 2:1-19.

Karadžić V, 2011. [Eutrofikacija i njene posledice na primeru reke Ponjavice (opština Pančevo)].[PhD Thesis in Serbian]. University of Belgrade, Serbia.

Karadžić V, Subakov-Simić G, Krizmanić J, Natić D, 2010. Phytoplankton and eutrophication development in the water supply reservoirs Garaši and Bukulja (Serbia). Desalination 255:91-96.

Karadžić V, Subakov-Simić G, Natić D, Ržaničanin A, Ćirić M, Gačić Z, 2013. Changes in the phytoplankton community and dominance of Cylindrospermopsis raciborskii (Wolosz.) Subba Raju in a temperate lowland river (Ponjavica, Serbia). Hydrobiologia 711:43-60.

Maslać M, Obušković Lj, Jakovčev D, Cakić P, Tucović V, 1992. [Previous investigations of Opovo channel, one in the system of channels of Pančevo, p. 28-33].[Article in Serbian]. In: Konferencija o aktuelnim problemima zaštite voda "Zaštita voda 92", Subotica.

Miljković D, Vučković M, Gotović D, Milenković P, Zarkov N, Roški Đ, 2004. Water supply problems of Majdanpek, p. 575-579].[Article in Serbian]. In: Konferencija o aktuelnim problemima zaštite voda "Zaštita voda 04", Borsko jezero.

Milovanović D, 1949. [Bibliografski pregled algoloških istraživanja u Srbiji do 1947. godine].[Article in Serbian]. Glasnik Prirodnjačkog muzeja u Beogradu Serija B: Biološke nauke B 1-2:323-329.

Milovanović D, 1963. Phytoplankton and primary production in fish ponds "Koluta". Arch. Biol. Sci. 6:3-16.

Milovanović D, 1970. Limnotypological changes of some waters as a consequence of meliorative works in river Dunav hydrosystem near Apatin. Ekologija 5:55-70.

Milovanović D, 1973. Phytoplankton structural changes in the first years of Đerdap reservoir existence. Arch. Biol. Sci. 25:75-83.

Milovanović D, Živković A, 1953. Plankton production investigations in Ečka fish ponds. Proceedings SAN 29:197-264. 
Milovanović D, Živković, A, 1959. Phytoplankton production in Živača fishpond (II Contribution to limnology of lentic waters in Panonia valley). Arch. Biol. Sci. 2:1-17.

Natić D, Jovanović D, Knežević T, Karadžić V, Bulat Z, Matović V, 2012. Microcystin-LR in surface water of Ponjavica River. Vojnosanit. Pregl. 69:753-758.

Obušković Lj, 1982. Phytoplankton and saprobiological characteristics of rivers Bosut, Spačva i Studva. Vodoprivreda 14:247-249.

Obušković Lj, 1983. [Das Phytoplankton des Stausees "Eisernes Tor" (Đerdap) im Jahre 1973].[Article in German]. Hidrobiologia 17:341-347.

Obušković Lj, 1987. [Phytoplankton and saprobiological characteristics of river Sava in 1984, p. 426-430].[Article in Serbian]. In: Proceedings Conf. River Sava, protection and water use, Zagreb.

Obušković Lj, 1989. [Phytoplankton and saprobiological characteristics of river Danube in 1988, p. 30-36].[Article in Serbian]. In: Proceedings Konferencija o aktuelnim problemima zaštite voda “Zaštita voda 89", Rovinj.

Obušković Lj, 1991. [Phytoplankton and saprobiological characteristics of river Ponjavice (South Banat) as indicator of increased eutrophication, p. 332-337].[Article in Serbian]. In: Proceedings Konferencija o aktuelnim problemima zaštite voda "Zaštita voda 91", Neum.

Perendija B, Despotović S, Radovanović T, Gavrić J, BorkovićMitić S, Pavlović S, Ognjanović B, Simić S, Pajović S, Saičić Z, 2011. Biochemical and ultrastructural changes in the liver of European perch (Perca fluviatilis L.) in response to cyanobacterial bloom in the Gruža reservoir. Arch. Biol. Sci. 63:979-989.

Protić Đ, 1935. [Hidrobiološke studije na Kanalu Kralja Petra i Kanalu Kralja Aleksandra. Drugi deo].[Article in Serbian]. Spomenik Srpske kraljevske Akademije 80:1-35.

Protić Đ, 1936. [Hidrobiološke studije na Kanalu Kralja Petra. Treći deo].[Article in Serbian]. Spomenik Srpske kraljevske Akademije 85:59-87.

Pujin V, Ratajac V, Đukić N, Svirčev Z, Kilibarda P, 1987. [Saisonmassige variationen des zusammemensetzung des planktons und der bodenbesiedlung in der Carska bara (Jugoslawien) ].[Article in German]. Tiscia (Szeged) 22:83-91.

Ristić O, Gajin S, Gantar M, Matavulj M, 1979. [Microbiological studies of some fish ponds in Vojvodina, p. 19231935].[Article in Serbian]. In: Proceedings II Congr. Ecologists in Yugoslavia, Zagreb.

Saqurane S, Ouahid Y, El Ghazali I, Oudra B, Bouarab L, Del Campo F, 2009. Physiological changes in Triticum durum, Zea mays, Pisum sativum and Lens esculenta cultivars, caused by irrigation with water contaminated with microcystins: a laboratory experimental approach. Toxicon 53:786-796.

Scharschmidt G, 1883. Fragmenta phycologiae Bosniaco - Serbicae].[Article in German]. Magyar novenytani lapok 75: 33-39.

Sedmak B, Svirčev Z, 2011. [Cijanobakterije i njihovi toksiniekološki i toksikološki rizici i cvetanje cijanobakterija u Srbiji].[Book in Slovenian]. Visoka šola za varstvo okolja, Velenje, Slovenia: $134 \mathrm{pp}$.

Seleši Đ, 1982. Limnological investigations of Lake Ludoš. Vode Vojvodine 10:345-368.

Shllaku L, Landner L, 1992. Environment in Kosovo: environ- mental problems related to mineral exploitation. Stockholm, Sweden, WHO.

Simeunović J, 2009. [Ekofiziološke karakteristike potencijalno toksičnih i toksičnih vodenih sojeva cijanobakterija na području Vojvodine].[PhD Thesis in Serbian], University of Novi Sad, Serbia.

Simić S, Mišćević S, Đorđević N, Popović N, 2011. Cyanobacteria in Aleksandrovac Lake - before and after revitalisation. In: Proceedings 16th Conf. Cyanobacteria and human health, Academy of Studenica, Novi Sad, Serbia.

Subakov-Simić G, Plemić N, Karadžić V, Cvijan M, Krizmanić J, 2004. [Qualitative and quantitative analysis of phytoplankton in Slatina near Opovo, p. 327-330].[Article in Serbian]. In: Proceedings Konferencija o aktuelnim problemima zaštite voda "Zaštita voda 04", Borsko jezero.

Svirčev Z, Simeunović J, Subakov-Simić G, Krstić S, Vidović, M, 2007. Freshwater cyanobacterial blooms and cyanotoxin production in Serbia in the past 25 years. Geographica Pannonica 11:12-21.

Svirčev Z, Krstić S, Miladinov-Mikov M, Baltić V, Vidović M, 2009. Freshwater cyanobacterial blooms and primary liver cancer epidemiological studies in Serbia. J. Environ. Sci. Heal. C 27:36-55.

Svirčev Z, Baltić V, Gantar M, Juković M, Stojanović D, Baltić M, 2010. Molecular aspects of microcystin-induced hepatotoxicity and hepatocarcinogenesis. J. Environ. Sci. Heal. C 28:39-59.

Svirčev Z, Simeunović J, Subakov-Simić G, Krstić S, Pantelić D, Dulić T, 2013a. Cyanobacterial blooms and their toxicity in Vojvodina lakes, Serbia. Int. J. Environ. Heal. R. 7:745-758.

Svirčev Z, Drobac D, Tokodi N, Vidović M, Simeunović J, Miladinov-Mikov M, Baltić V, 2013b. Epidemiology of primary liver cancer in Serbia and possible connection with cyanobacterial blooms. J. Environ. Sci. Heal. C 31:181-200.

Svirčev Z, Tokodi N, Drobac D, Codd GA, 2014a. Cyanobacteria in aquatic ecosystems in Serbia: effects on water quality, human health and biodiversity. Syst. Biodivers. 12: 261-270.

Svirčev Z, Drobac D, Tokodi N, Lužanin Z, Munjas Am, Nikolin B, Vuleta D, Meriluoto J, 2014b. Epidemiology of cancers in Serbia and possible connection with cyanobacterial blooms. J. Environ. Sci. Heal. C 32:319-337.

Svirčev Z, Obradović V, Codd GA, Marjanović P, Spoof L, Drobac D, Tokodi N, Petković A, Nenin T, Simeunović J, Važić T, Meriluoto J, 2016a. Massive fish mortality and Cylindrospermopsis raciborskii bloom in Aleksandrovac Lake. Ecotoxicology 25:1353-1363.

Svirčev Z, Drobac D, Tokodi N, Đenić D, Simeunović J, Hiskia A, Kaloudis T, Mijović B, Šušak S, Protić M, Vidović M, Onjia A, Nybom S, Važić T, Palanački Malešević T, Dulić T, Pantelić D, Vukašinović M, Meriluoto J, 2016b. Lessons from the Užice case: how to complement analytical data. In: J. Meriluoto, L. Spoof and G.A. Codd (eds.), Handbook of cyanobacterial monitoring and cyanotoxin analysis. J. Wiley \& Sons, Chichester: 576 pp.

Tokodi N, Drobac D, Simeunović J, Svirčev Z, 2013. Assessment of acute cyanotoxicity using Artemia salina bioassay in water samples from fishponds. In: $17^{\text {th }}$ International EcoConference, $10^{\text {th }}$ Environmental protection of urban and suburban settlements. 25-28 September 2013, Novi Sad, Serbia. 
Tokodi N, Drobac D, Simeunović J, Svirčev Z. 2014. Microcystin concentrations in fishpond waters. Matice Srpska J. Nat. Sci. 127:35-42.

Tokodi N, 2016. [Toksične cijanobakterije sa teritorije Republike Srbije].[PhD Thesis in Serbian], University of Novi Sad, Serbia.

WHO, 1999. Toxic cyanobacteria in water: A guide to their pub- lic health consequences, monitoring, and management. World Health Organization, Geneva, Switzerland.

World Bank Report, 2011. Introducing Daphnia grazing to control global warming - associated cyanobacterial toxic blooms in fishing pond. Report DM 4307. In: World Health Organization 1998. Guidelines for drinking-water quality, 2nd ed. Addendum to vol. 2. WHO, Geneva, Switzerland. 